\title{
Changes in coastline positions during the Holocene in the shelf of the Northwestern Black Sea
}

\author{
Natalia Tyuleneva*, Igor Suchkov, Natalia Fedoronchuk \\ Geological-Geographical Faculty, Department of Physical and Marine Geology, Odessa I.I. Mechnikov National University, Shampansky Per., 2, \\ Odessa 65058, Ukraine
}

\section{A R T I C L E I N F O}

Article history:

Available online 17 August 2013

\begin{abstract}
A B S T R A C T
The first evidence for the reconnection of the Black Sea with the Mediterranean Sea are euryhaline mollusc species that appear in the bottom sediments. Lacustrine conditions existed over the larger part of study area at the beginning of the Holocene. Early Holocene beds are characterized by a wide distribution of continental facies (e.g. lacustrine-marshy and alluvial). The lacustrine phase was followed by a marine phase and the transition occurred around ca. 8.9-8.5 ka BP. The Holocene was marked by a gradual increase of Mytilus sp. shells in sediments. Reconstructions of coastline positions during the Holocene in the Northwestern Black Sea shelf are presented. Extensive sampling of the study area during several decades allowed the acquisition of a comprehensive data base for paleogeographic reconstructions. Positions of ancient coastlines are discussed. Analysis of relief features, lithological composition and bottom sediments distribution and faunal complexes allowed identification of paleofacies in the northwestern part of the Black Sea. Facial and paloegeographic maps of the Holocene discrete time intervals such as the Bugazian (from ca. 10.5-10 to 8.9-8.5 ka BP), the Vityazevian (from ca. 8.9-8.5 to 7.1-6.2 ka BP), the Kalamitian (from ca. 7.1-6.2 to 4.1-4.0 ka BP), and the Dzhemetinian (from ca. 4.1-4.0 to present) are presented. Dating of the sediments is based on uncalibrated radiocarbon determinations. Study of the granulometry of sediments provided evidence that supports the proposed ancient coastline positions. The samples from the cores recovered from different facial zones enabled the characterization of sedimentological environments for each time interval. The position of the early Holocene coastal sediments is marked out on the level of modern isobaths approximately from -25 to $-35 \mathrm{~m}$. In the range of time from ca. 8.9-8.5 to 7.1-6.2 ka BP, the coastline was located at depths from 20 to $25 \mathrm{~m}$. The position of the coastline which existed from ca. 7.1-6.2 to 4.1-4 ka BP is allocated on the level of modern isobaths from -0 to $-15 \mathrm{~m}$. Comparison of the various positions of the coastline and their facies changes through time indicates that the Holocene transgression had a progressively and oscillatory course.
\end{abstract}

(c) 2013 Elsevier Ltd and INQUA. All rights reserved.

\section{Introduction}

The history of the geological development of the shelf of the Northwestern Black Sea during the Holocene was studied for more than 100 years, but discussion still persists concerning the course of the Holocene transgression. Investigations on the coastal areas of the Black Sea have been carried out by many scientists such as Zenkovich (1962), Nevesskiy (1967), Ishenko (1971), Sherbakov and Morgunov (1975), Pazyuk et al. (1977), Barkovskaya (1982), Molodikh et al. (1984), Shnyukov et al. (1985, 1998), Emelianov et al. (2004), Chepalyga (2006), Mitropolskiy et al. (2006),

\footnotetext{
* Corresponding author.

E-mail address: natalia.tyuleneva@gmail.com (N. Tyuleneva).
}

Ivanova et al. (2007), Konikov (2007), Lericolais et al. (2007), Yanko-Hombach (2007), Yanko-Hombach et al. (2011), and Giosan et al. (2009).

The first biostratification of late Pleistocene and Holocene bottom sediments was carried out by Andrusov (1926). Later, the biostratification by Andrusov was revised by Arkhangelsky and Strakhov (1938), who marked out the Chernomorian horizon with such mollusc species as Mytilus sp. and Modiolus sp. Nevesskaya and Nevesskiy (1961) established the subdivision of the Drevnechernomorian subhorizon into the Bugazian-Vityazevian and Kalamitian layers, and the subdivision of the Novochernomorian subhorizon into the Dzhemetinian layer. Gozhik et al. (2006) associated the Bugazian-Vityazevian layers to the Drevnechernomorian subhorizon, the Kalamitian layers to the Novochernomorian subhorizon and the Dzhemetinian layers to the present subhorizon. 
Nevesskaya (1965), Tsereteli (1975), Fedorov (1978) made extensive researches of sedimentation features in the inner parts of the Black Sea shelf. Later, Balabanov and Izmailov (1988), Chepalyga (2002), Yanko-Hombach (2007), supplemented notions of this area with new data which allowed to mark out transgressive and regressive phases in the curse of the Holocene sea level changes. Transgressive and regressive (underlined) phases were clearly indentified in the study area in the following subsequence: Bugazian, Kolkhidian, Vityazevian, Pontian, Kalamitian, Eggrisian, Dzhemetinian, Phanagorian, Nymphaean, Korsunian, and Recent. According to Yanko $(1989,1990)$ the rise of the sea level was gradual with halts and regressive phases and was not rapid.

During the few last decades, notions about Late PleistoceneHolocene paleogeography were extended, new data about Black Sea level fluctuation appeared, and the interpretations were commonly conflicting. Some investigators suggested that the transition from brackish to marine environment in the Black Sea was abrupt (Ryan et al., 1997, 2003, 2013) while others deny any catastrophic events and suggested that the process lasted several thousand years (Aksu et al., 2002).

Recent studies of the paleontology and the sedimentology of the NW Black Sea shelf enabled revision of the history of geological development, and illumination of the sedimentation environments and the alterations of the position of the coastline in the study area. The changes in these elements are regarded as integral parts of the ecosystem of the Black Sea and indicate the environmental variations that shaped it. investigation are based on extensive sampling of bottom sediments, analyzing more than 3000 gravity and piston cores and 250 boreholes. These data are the results of previous geological surveys which were carried out by Prichernomorskoe State Regional Geological Enterprise "Prichernomor GRGP" (Odessa, Ukraine) and Odessa I.I.Mechnikov National University. The grain size analysis was carried out in the laboratories of these establishments and the data base with the results of particle size analysis was used to determine granulometric coefficients. Sediment particle sizes were determined by means of standard methods (Petelin, 1967; Chapovsky, 1975) which included dry and wet sieve analysis. For the particle sizes of less than $0.05 \mathrm{~mm}$, the method is based on Stokes' law describing the rate of sedimentation of particles suspended in water was applied.

Holocene transgression features were studied by means of reconstruction the position of coastlines in discrete time intervals: from ca. 10.5-10 to 8.9-8.5 ka BP (Bugazian beds), from ca. 8.9-8.5 to 7.1-6.2 ka BP (Vityazevian beds), from ca. 7.1-6.2 to 4.1-4 ka BP (Kalamitian beds) and from ca. 4.1-4 to present (Dzhemetinian beds). The regional subdivision for the Holocene sediments of the NW part of the Black Sea charted by Sibirchenko et al. (1983) (Table 1) was used. The determinations of sediment ages are based also on the results of the bulk, uncalibrated radiocarbon dating of Sibirchenko et al. (1983). The results of radiocarbon dating are not corrected according to the reservoir effect due to the uncertainty in the correction. That is why the precision may vary over wide ranges (Major et al., 2006).

Table 1

Regional stratigraphy of the Holocene marine sediments (Sibirchenko et al., 1983).

\begin{tabular}{|c|c|c|c|c|}
\hline \multicolumn{5}{|c|}{ Marine formation } \\
\hline Section & Horizon & Subhorizon & Layer & $\begin{array}{l}\text { Age of stratigraphic } \\
\text { base (ky BP) }\end{array}$ \\
\hline Holocene $\mathrm{H}$ & Chernomorian, čm & & $\begin{array}{l}\text { Dzhemetinian dž } \\
\text { Kalamitian kl }\end{array}$ & $\begin{array}{l}\text { ca. } 4.1-4 \\
\text { ca. } 7.1-6.2\end{array}$ \\
\hline & & Drevnechernomorian, čm 1 & $\begin{array}{l}\text { Vityazevian vz } \\
\text { Bugazian bz }\end{array}$ & $\begin{array}{l}\text { ca. } 8.9-8.5 \\
\text { ca. } 10.5-10\end{array}$ \\
\hline
\end{tabular}

The aim of this work is the paleogeographical reconstructions within the northwestern Black Sea shelf during the Holocene on the basis of lithological characteristics of the Bugazian (from $\mathrm{ca}$. 10.5-10 to 8.9-8.5 ka BP), Vityazevian (from ca. 8.9-8.5 to 7.1-6.2 ka BP), Kalamitian (from ca. 7.1-6.2 to 4.1-4 ka BP) and Dzhemetinian (from $\mathrm{ca}$. 4.1-4 to present) layers of the Holocene sediments, the names of which correspond to transgressive phase names.

\section{Regional setting}

The study area is the northwestern Black Sea shelf (Fig. 1). The northern boundary of the area is the modern coastline, and its southern boundary is the modern isobaths of $50-55 \mathrm{~m}$. The northwestern Black Sea shelf's recent underwater landscapes were formed during the Holocene transgression, when subaerial flats were flooded. Recent submarine relief is inherited and was smoothed in the course of the transgression (Shnyukov et al., 1998; Fesyunov, 2000; Sorokin and Kuprin, 2007).

\section{Materials and methods}

Many cores were collected in the study area during the period from 1976 to 2006 across the whole northwestern continental shelf of the Black Sea (Fig. 1). The results of the present

\section{Results and discussion}

The presented reconstructions of the positions of coastline of the NW Black Sea during Holocene were based on the following indicators: presence or absence of bottom sediments, the lithology of bottom sediments, changes of facies, and pre-Holocene and recent relief features. Facies and subfacies of bottom sediments of the studied time intervals were also marked out. Furthermore, results of investigation, previously obtained by authors (Tyuleneva, 2010; Tyuleneva and Suchkov, 2011) were used.

\subsection{Bugazian beds (from ca. $10.5-10$ to $8.9-8.5 \mathrm{ka} \mathrm{BP}$ )}

The beginning of the early Holocene transgression was dated to ca. 10.5-10 ka BP by Sibirchenko et al. (1983). Bottom sediments of this sub-stage are characterized by a wide granulometric spectrum ranging from silt and clayey mud to sands and shell sediments, which show irregular and mosaic distribution within the study area (Fig. 2).

The marine facies are represented by sands, shell sediments, silt, and mud. These sediments include first euryhaline immigrants such as Mytilus galloprovincialis, Cardium edule (Linne), Cardium exiguum, Abra ovata (Phil.), Hydrobia ventrosa (Mont.) and Rissoa sp. A few shells of these species are encountered only in a few cores recovered in a water depth between -30 and $-40 \mathrm{~m}$. 

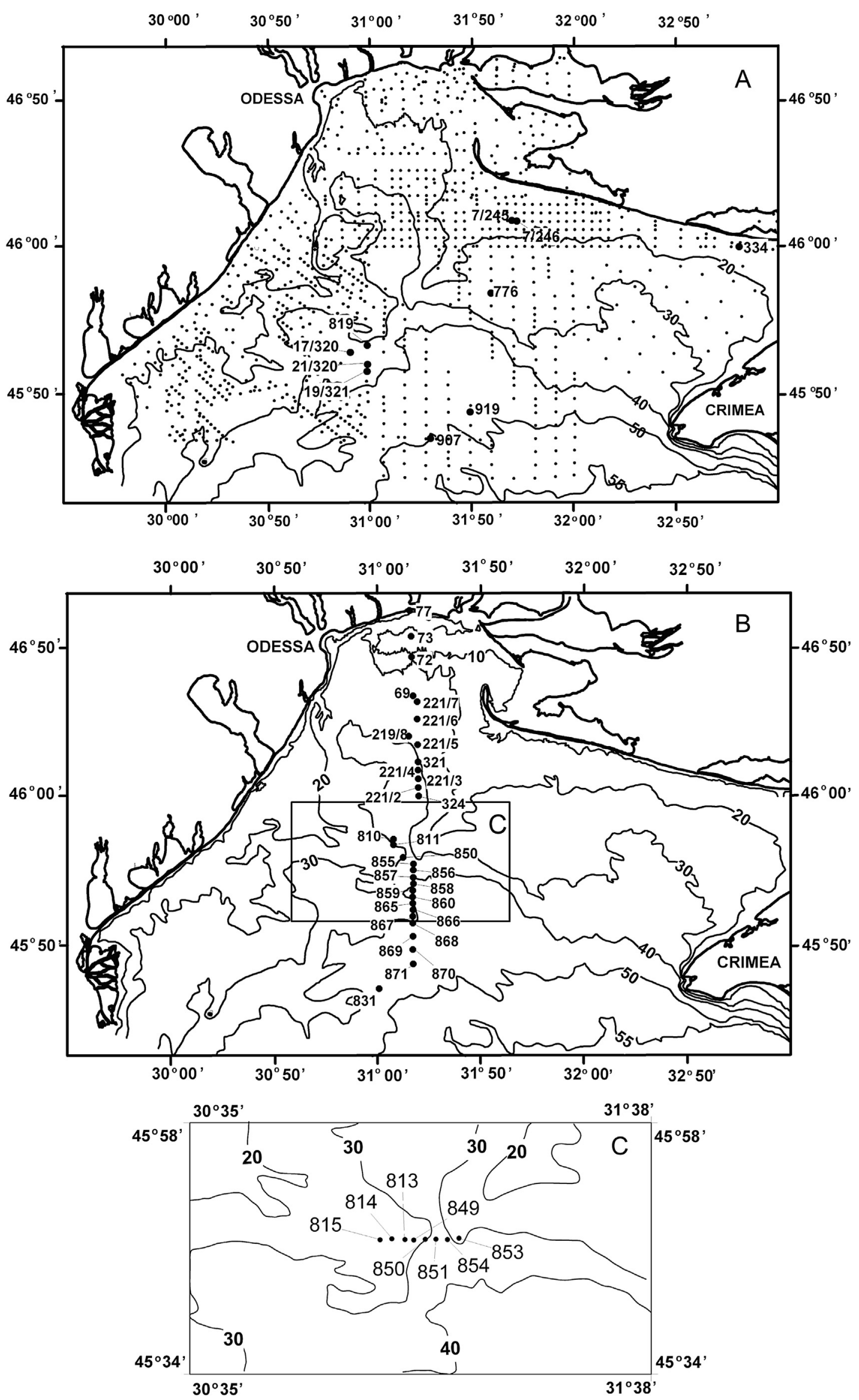

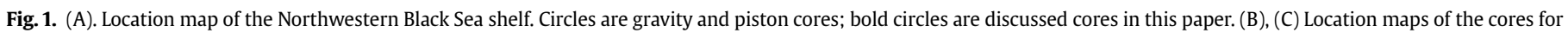
constructed sections. Isobaths are in meters. 


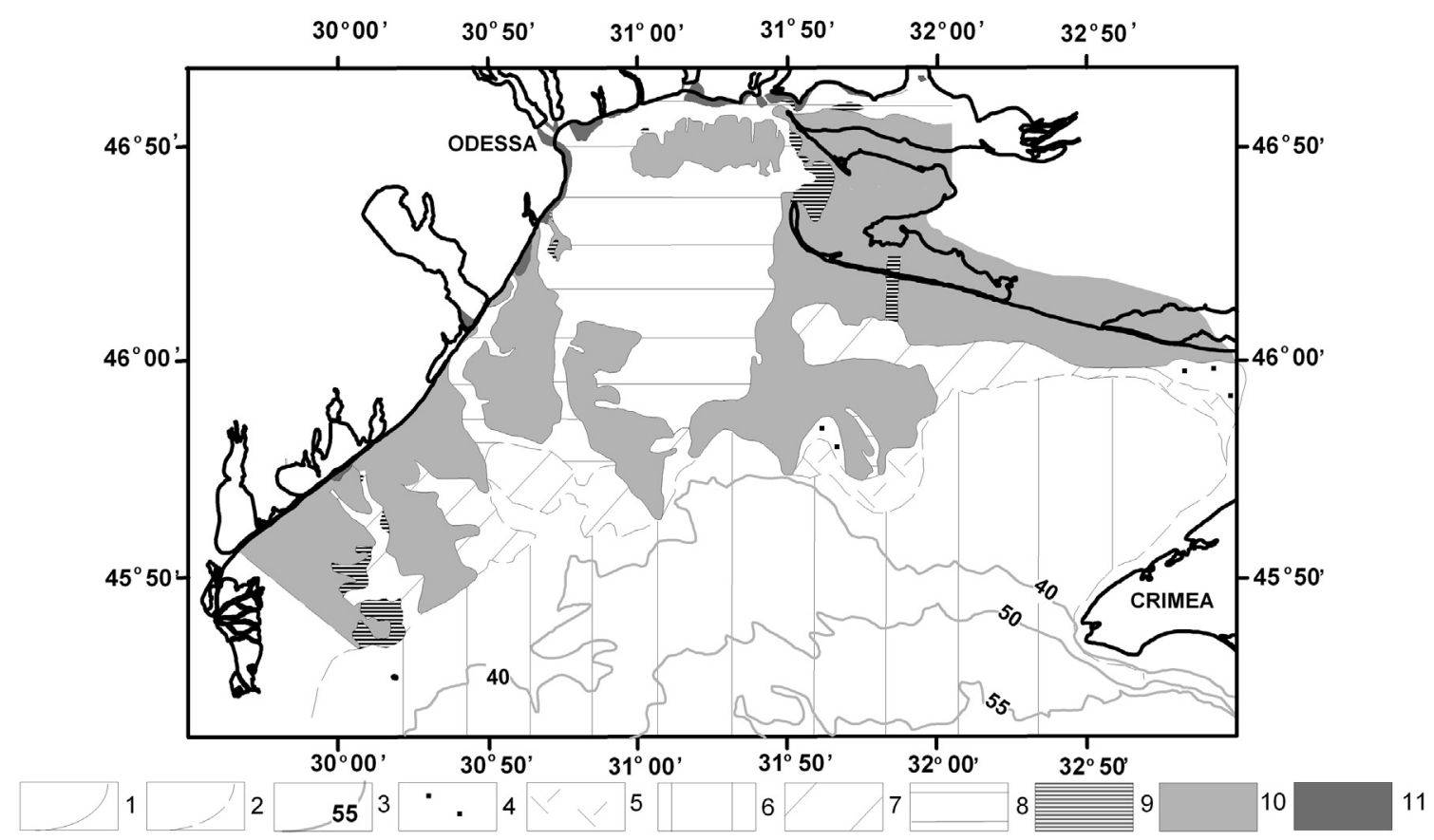

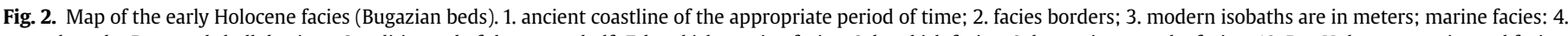

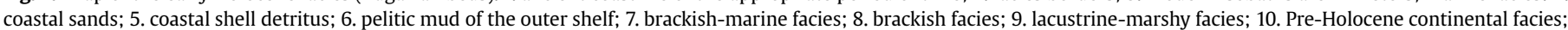
11. Pre-Quaternary sediments.

The marine facies can be subdivided into three subfacies coastal sands, coastal shell detritus, and pelitic mud of the outer shelf. Brackish-marine sediments are represented mostly by silt and pelitic mud in the central part of the study area.

The brackish facies is represented by sands with addition of shells, shell detritus, silt; and also by shell sediments with addition of sand, silt and clay; also abundant are silt and clayey mud. Lake sediments contain brackish water mollusc assemblages typical for Neoeuxinian beds such as Dreissena polymorpha (Pallas), Dreissena rostriformis bugensis (Andr.), Monodacna caspia pontica (Nev.), Clessiniola variabilis (Eichw.), Turricaspia caspia lincta (Mil.), Turricaspia variabilis (Eichw.), with numerous limnetic species Lithoglyphus naticoides (C. Pff.), Viviparus viviparus (L.), Viviparus fasciatus (Miill.). The lacustrine-marsh facies is represented by peat, silt, and clay, with plant residues. Rare species of molluscs such as Lithoglyphus naticoides (C.Pff.), D. polymorpha (Pallas), D. rostriformis (Desh.) and Viviparus viviparus (Linne) can be found.

The coastline during this period was indented with broad bays and limans. This configuration of the early Holocene coastline is indicated by the paleofacies reconstruction (Fig. 2) and geology (Fig. 3). The section shows that the Holocene sediments fill a paleoriver valley.

The distribution of the marine bottom sediments is marked out on the level of modern isobaths approximately from -25 to $-35 \mathrm{~m}$ (Fig. 2). The position of the coastline was confirmed by the results of granulometric composition analysis, and also by the presence of brackish, brackish-marine and lacustrine-marsh facies sediments.

To determine the coastline position, the granulometric coefficients were calculated. The samples from core $776\left(45^{\circ} 50.483^{\prime}\right.$ $\mathrm{N}-31^{\circ} 35.967^{\prime} \mathrm{E}$, water depth $-24.3 \mathrm{~m}$ ) and 334 (position $46^{\circ} 00^{\prime}$ $\mathrm{N}-32^{\circ} 48.701^{\prime} \mathrm{E}$, water depth $-12.5 \mathrm{~m}$ ) were studied. The cores were recovered from the coastal sands zone. The sediments are characterized by low sorting coefficients $\left(S_{0}=1.28\right.$ and $S_{0}=1.44$, respectively) which means that the sediments had undergone mechanical separation within the paleocoastal zone. Another pattern far from the coastal zone can be noted in deeper water. Cores $907\left(45^{\circ} 20.801^{\prime} \mathrm{N}-31^{\circ} 18.162^{\prime} \mathrm{E}\right.$, water depth $\left.-47.6 \mathrm{~m}\right)$ and $919\left(45^{\circ} 26.143^{\prime} \mathrm{N}-31^{\circ} 29.893^{\prime} \mathrm{E}\right.$, water depth $\left.-47.4 \mathrm{~m}\right)$ in the clayey mud facies zone of the outer shelf were studied. The samples have high sorting coefficients $\left(S_{0}=3.53\right.$ and $S_{0}=3.23$, respectively). The appearance of admixtures of whole shells or of their detritus in sand and mud cause increments of sorting coefficients, and therefore the sediments are less sorted.

At the end of Bugazian time, a slight regression happened, and its marks are visible in the structure and the lithology of the bottom sediments along the ancient coastline at a water depth of $30 \mathrm{~m}$. The Bugazian beds in core 819 (core length $120 \mathrm{~cm}, 45^{\circ} 37.297^{\prime} \mathrm{N}-$ $30^{\circ} 59.418^{\prime}$ E) are represented by two layers (Fig. 4). From the bottom to top, the first layer consists of shell sediments with mollusc shells without marks of erosion. These sediments can be encountered in modern conditions on the shelf away from the coastal zone. The second layer is formed mostly by well-sorted sands, and admixtures of shell detritus. This layer could have accumulated close to shore under conditions of high wave energy.

\subsection{Vityazevian beds (from ca. 8.9-8.5 to $7.1-6.2 \mathrm{ka} \mathrm{BP}$ )}

Bottom sediments are represented by marine, brackish-marine and brackish facies (Fig. 5). The marine facies of this age can be divided into two subfacies - marine mud, and marine sand-andshell sediments. The typical fauna for these sediments are Cardium edule, Corbula mediterranea and Abra ovata. Mud sediments with addition of silt, sand, and shells in places are distributed within the Dnieper and Dniester depressions. The location of relief forms on the shelf is shown in Fig. 6. On the slopes of Western Tendrovskaya, the SE part of the Dniester and Odessa elevations, coarse sand and shell sediments are distributed. On the coastal part the contemporaneous sediments are represented by medium and fine grained sand and by mud and silt in the bays and the limans.

The sediments distributed in the brackish-marine facies are silt, mud with addition of mollusc shells, shell sediments and sands, and plant residues are present. The brackish facies consists of silt, with rare addition of shells and sand. These sediments contain 


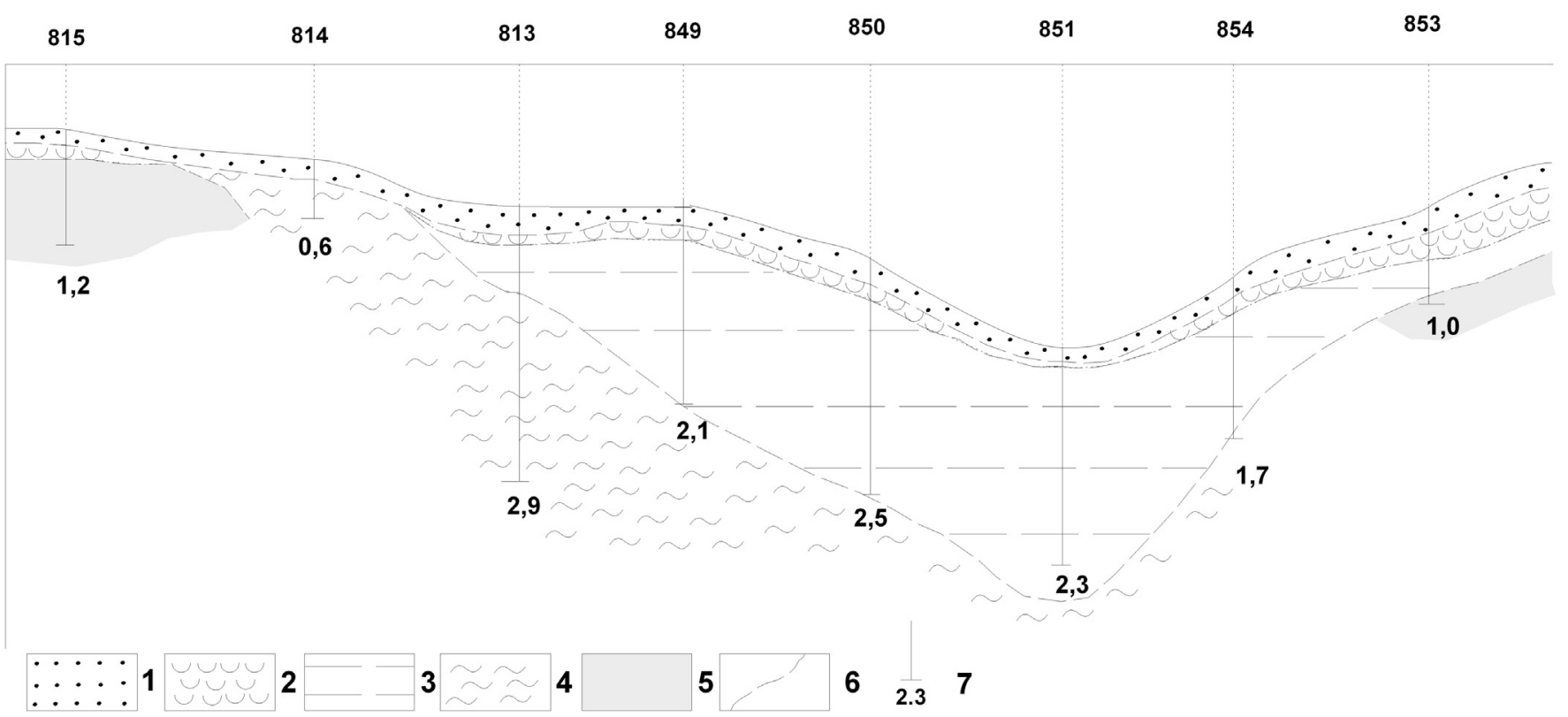

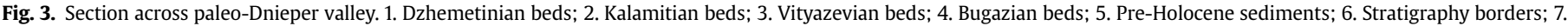
Cores and penetration depths (in meters).

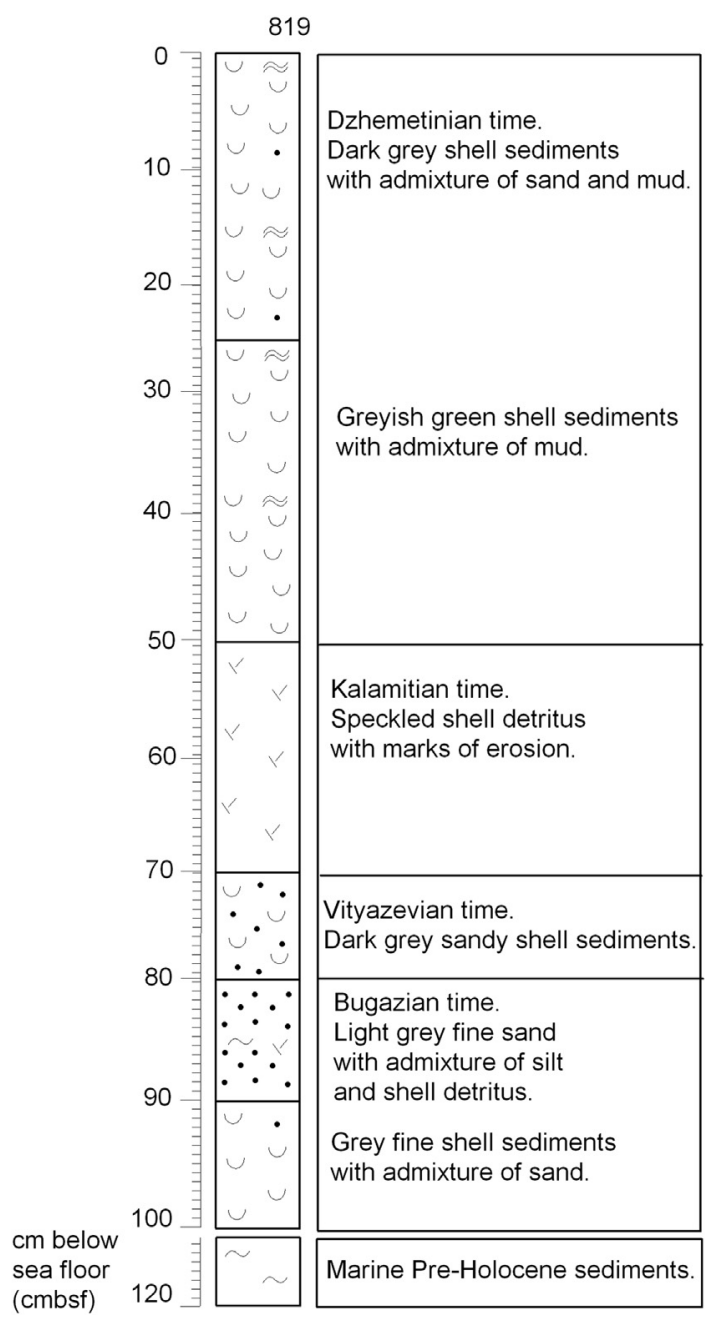

Fig. 4. Core 819 (position $45^{\circ} 37.297^{\prime} \mathrm{N}-30^{\circ} 59.418^{\prime} \mathrm{E}$, water depth $30 \mathrm{~m}$ ). mollusc species such as Hypanis angusticostata angusticostata (Borrea), Hypanis plicata relicta (Mil.), D. polymorpha (Pall.), D. rostriformis bugensis (Andr.), Adacna vitrea euxinica (Nev.) and Valvata piscinalis (Miill.). Species encountered within mostly desalinated areas were: Turricaspia caspia lincta (Mil.), Turricaspia variabilis (Eichw.), Turricaspia pseudotriton (Eichw.), Lithoglyphus naticoides (C. Pff.), Viviparus viviparus (L.), Viviparus fasciatus (Miill.), and Theodoxus pallasi (Lindholm).

The Vityazevian coastline is located at depths from 20 to $25 \mathrm{~m}$, and its outline is characterized by the presence of bays and limans (Fig. 5). The sediments from cores $7 / 245\left(46^{\circ} 5.275^{\prime} \mathrm{N}-31^{\circ} 41.952^{\prime} \mathrm{E}\right.$, water depth $-14.5 \mathrm{~m}$ ) and core $7 / 246$ (position $46^{\circ} 5.237^{\prime} \mathrm{N}-$ $31^{\circ} 43.242^{\prime} \mathrm{E}$, water depth $\left.-14.5 \mathrm{~m}\right)$ are well sorted $\left(S_{0}=1.8\right.$ and $S_{0}=1.45$, respectively) indicating the vicinity of the coastline. These sediments were formed under the influence of high hydrodynamic activity. On the outer shelf in the sample from core 919 (position $45^{\circ} 26.143^{\prime} \mathrm{N}-31^{\circ} 29.893^{\prime} \mathrm{E}$, water depth $-47.4 \mathrm{~m}$ ) sorting coefficients become higher $\left(S_{0}=3\right)$.

At the end of Vityazevian time, indications of alteration of water depth can be found. The lithology and structure of core 17/320 (core length $220 \mathrm{~cm}, 45^{\circ} 38.386^{\prime} \mathrm{N}-30^{\circ} 54.629^{\prime} \mathrm{E}$, water depth $-31.1 \mathrm{~m}$ ) is shown in Fig. 7. The Vityazevian beds consist of three layers which have different lithological composition. From the bottom to the top, the first layer is represented by shell sediments with admixed sand. The second layer is formed by shelly sand, and the third by clayey shell sediments and admixtures of sand. The first and the third layers could be formed when the coast was situated farther to the north in currently deeper marine environments. The sediments from the second layer, according to its composition, could have formed close to the shore area.

Vityazevian beds are absent in core 21/320 (core length $150 \mathrm{~cm}, 45^{\circ} 35.933^{\prime} \mathrm{N}-30^{\circ} 59.650^{\prime} \mathrm{E}$, water depth $-38 \mathrm{~m}$ ) (Fig. 8). Probably, they were eroded and destroyed in the course of the regression before Kalamitian time. The sediments in the upper part of the Vityazevian beds from core 9/321 (core length $130 \mathrm{~cm}$, $45^{\circ} 34.500^{\prime} \mathrm{N}-30^{\circ} 59.493^{\prime} \mathrm{E}$, water depth $-39.1 \mathrm{~m}$ ) (Fig. 9) bear marks of erosion processes. We assume that presence of scour surface can indicate alternating water depth, possibly caused by regression. 


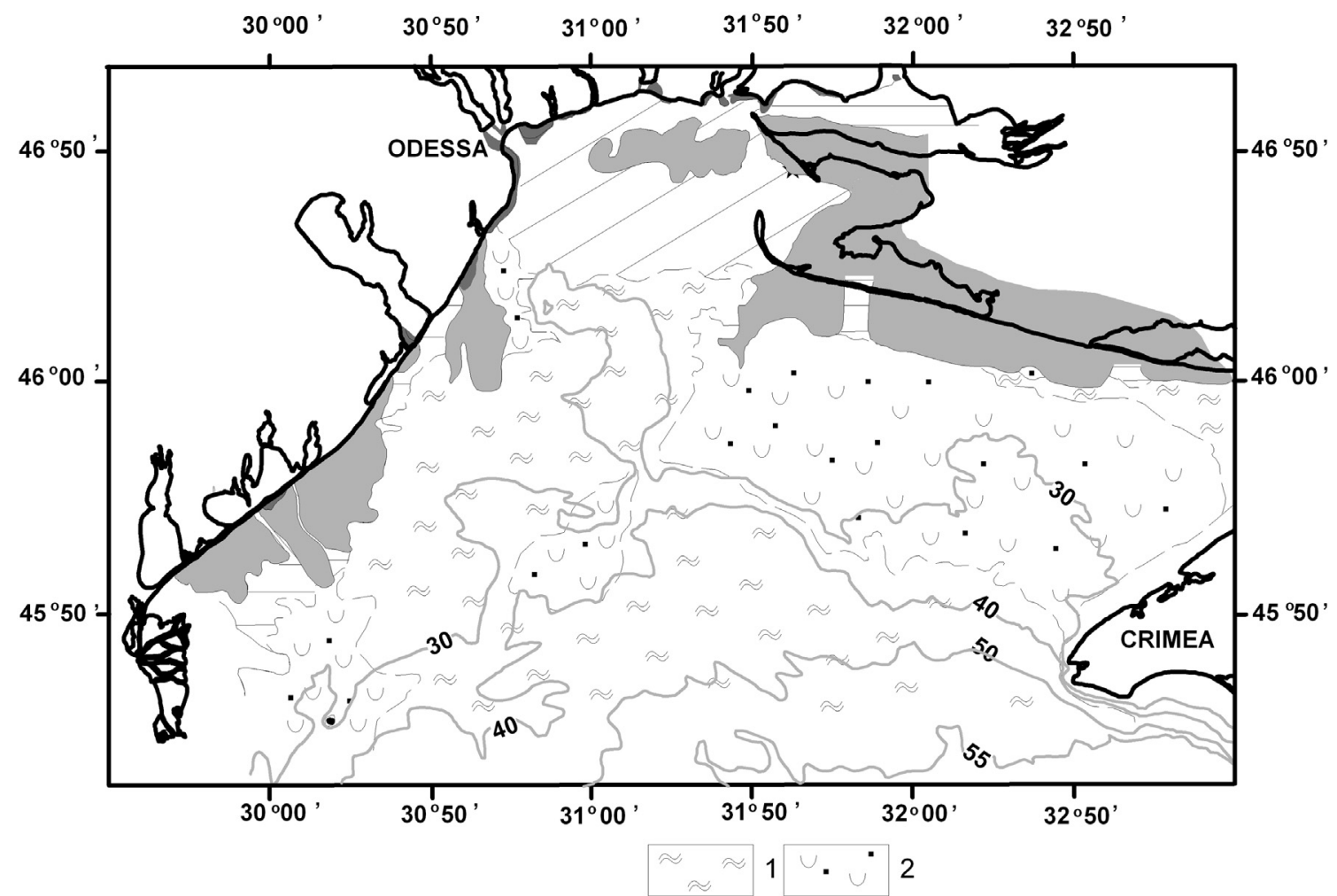

Fig. 5. Map of the Vityazevian facies. See Fig. 2 for captions. marine facies: 1. marine mud; 2 . marine sands and shell sediments.

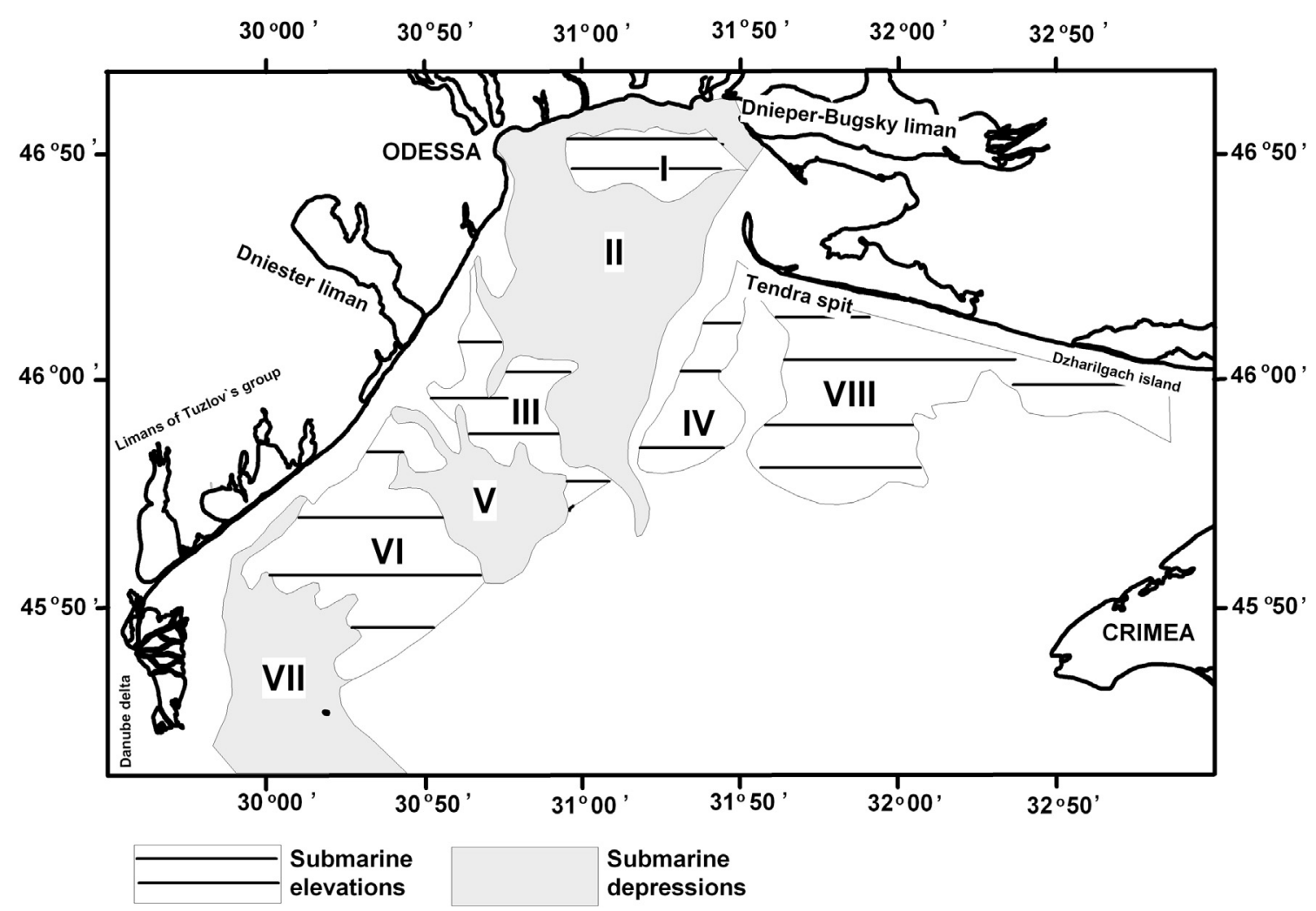

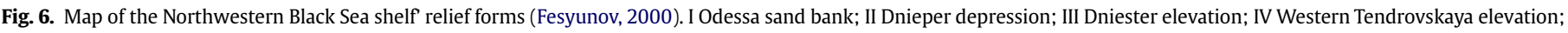
V Dniester depression; VI Budakskoe elevation; VII Palo-Sarata; VIII Tendra elevation. 


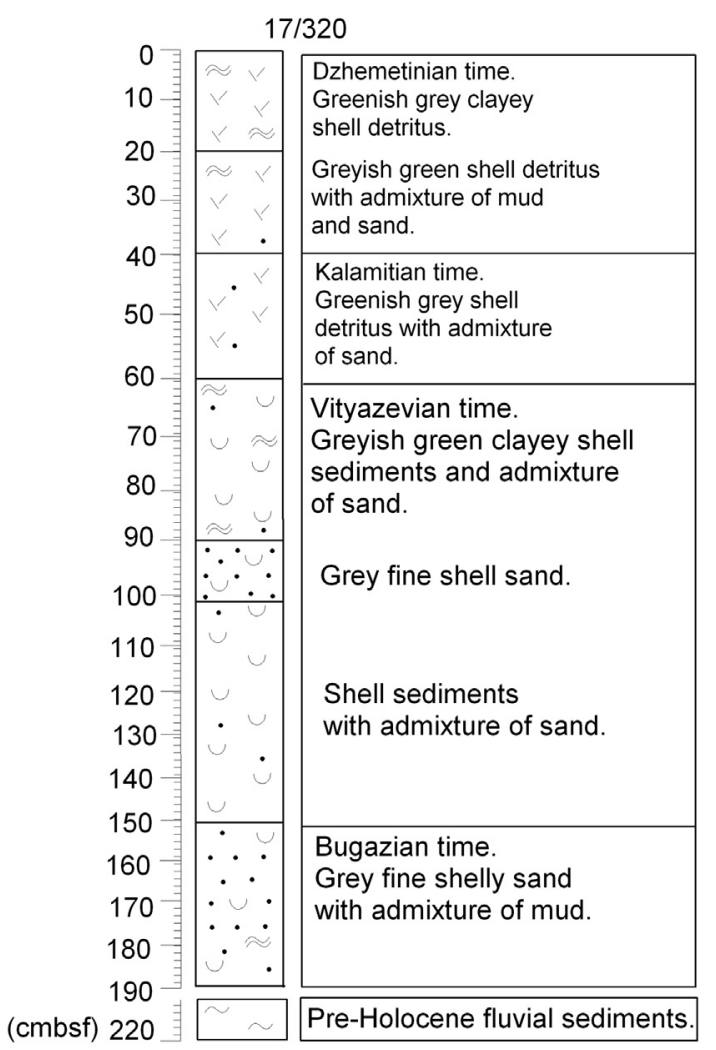

Fig. 7. Core $17 / 320$ (position $45^{\circ} 38.386^{\prime} \mathrm{N}-30^{\circ} 54.629^{\prime} \mathrm{E}$, water depth $31.1 \mathrm{~m}$ ).

\subsection{Kalamitian beds (from ca. 7.1-6.2 to 4.1-4 ka BP)}

The Kalamitian bottom sediments are represented by marine, brackish-marine and brackish facies (Fig. 10). The marine facies, from south to north, can be subdivided into three subfacies units marine shell sediments, marine mud, and marine coastal shell sediments and sand. The subfacies of marine shell sediments is widespread beneath the $15 \mathrm{~m}$ isobath, but in several areas (for example Dniester liman area, the limans of Tuzlov's group (Fig. 6)) sediments of this subfacies are situated within the coastal zone. Shell sediments are medium to fine grained, grey with olive hue,

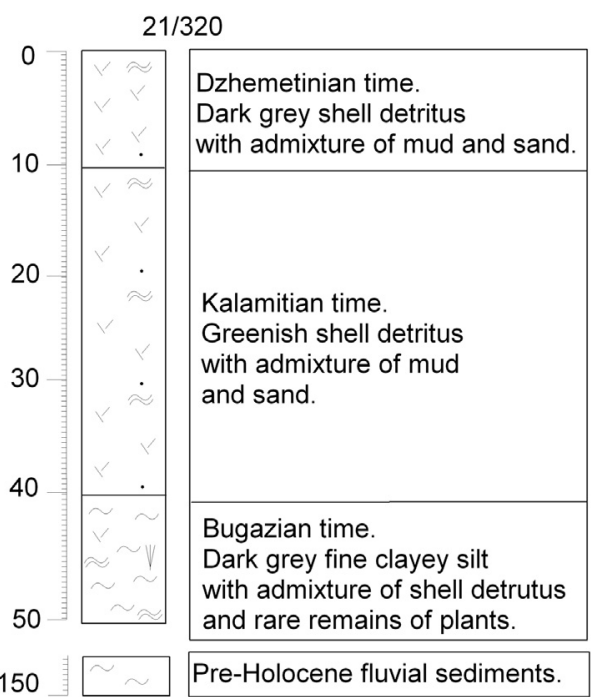

Fig. 8. Core $21 / 320$ (position $45^{\circ} 35.933^{\prime} \mathrm{N}-30^{\circ} 59.650^{\prime} \mathrm{E}$, water depth $38 \mathrm{~m}$ ).

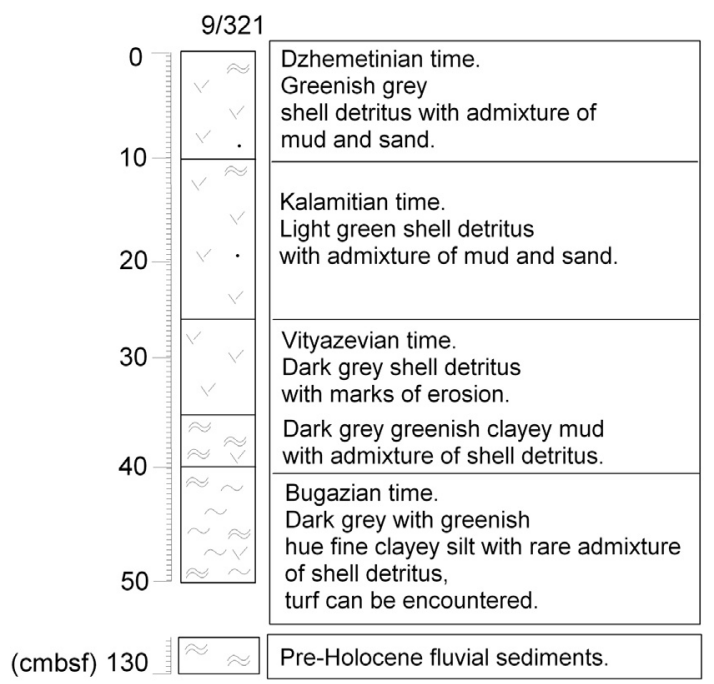

Fig. 9. Core $9 / 321$ (position $45^{\circ} 34.500^{\prime} \mathrm{N}-30^{\circ} 59.493^{\prime} \mathrm{E}$, water depth $39.1 \mathrm{~m}$ ).

with silt and sand, and contain mollusc species such as M. galloprovincialis, Cardium exiguum, Cardium edule, Rissoa parva, Rissoa membranacea, Bittium reticulatum and Mytilaster lineatus. The subfacies of marine mud is distributed in the Dnieper depression, and also in a small area near the Dniester liman and Dzharilgach island. Clayey and silt mud sediments are distributed within the Dnieper depression (Fig. 6). The subfacies of marine coastal shell sediments and sand is distributed within the western part of the Dniester elevation and on the slopes of the Tendra elevation (Fig. 6). The brackish-marine facies is distributed above $-25 \mathrm{~m}$ in the Dnieper depression. These facies consist of clayey mud with admixtures of shell detritus material. Sand and shell sediments are distributed on the slopes of Odessa sandbank and between Kinburnskaya and Tendra spits. The brackish facies of the Kalamitian beds is distributed mostly within recent limans. In the DnieperBugsky liman, this facies is consists of silt and clayey mud, but on the coastal part it is built of sand with addition of shell detritus. The mollusc assemblages contain marine and brackish water species.

The data indicate the position of the Kalamitian coastline from -10 to $-15 \mathrm{~m}$ (Fig. 10). Outlines of the coastline are smoother in comparison to the older coastlines, but small bays still existed along the shore. In the area of Dniester liman, Tendra spit and the northern part of the study area, there are places of erosion where the Drevnechernomorian sediments are exposed. It seems that after Kalamitian stage of the transgression, a slight drop (about $10 \mathrm{~m}$ ) of sea level occurred.

\subsection{Dzhemetinian beds (from ca. 4.1-4 ka BP to present)}

The present coastline was formed at this time. Limans were separated from the sea by sand spits, and transformed into enclosed lakes. The Odessa sandbank and bench became flooded by the sea and as a result, erosion became more active. The Dzhemetinian beds have transgressive overlap on the Kalamitian marine and liman sediments below isobaths $8-15 \mathrm{~m}$. They are represented by sand and shell sediments in the coastline area and on the elevations and by silt in the depressions and the limans. Dzhemetinian facies presented by the brackish and the marine sediments are shown in Fig. 11.

Marine sediments can be divided into two subfacies: marine silt and clayey mud with shells and marine shell sediments and sand. The subfacies of silt and clayey mud with shells is distributed in depressions and is represented by grey mud with mollusc shells: 


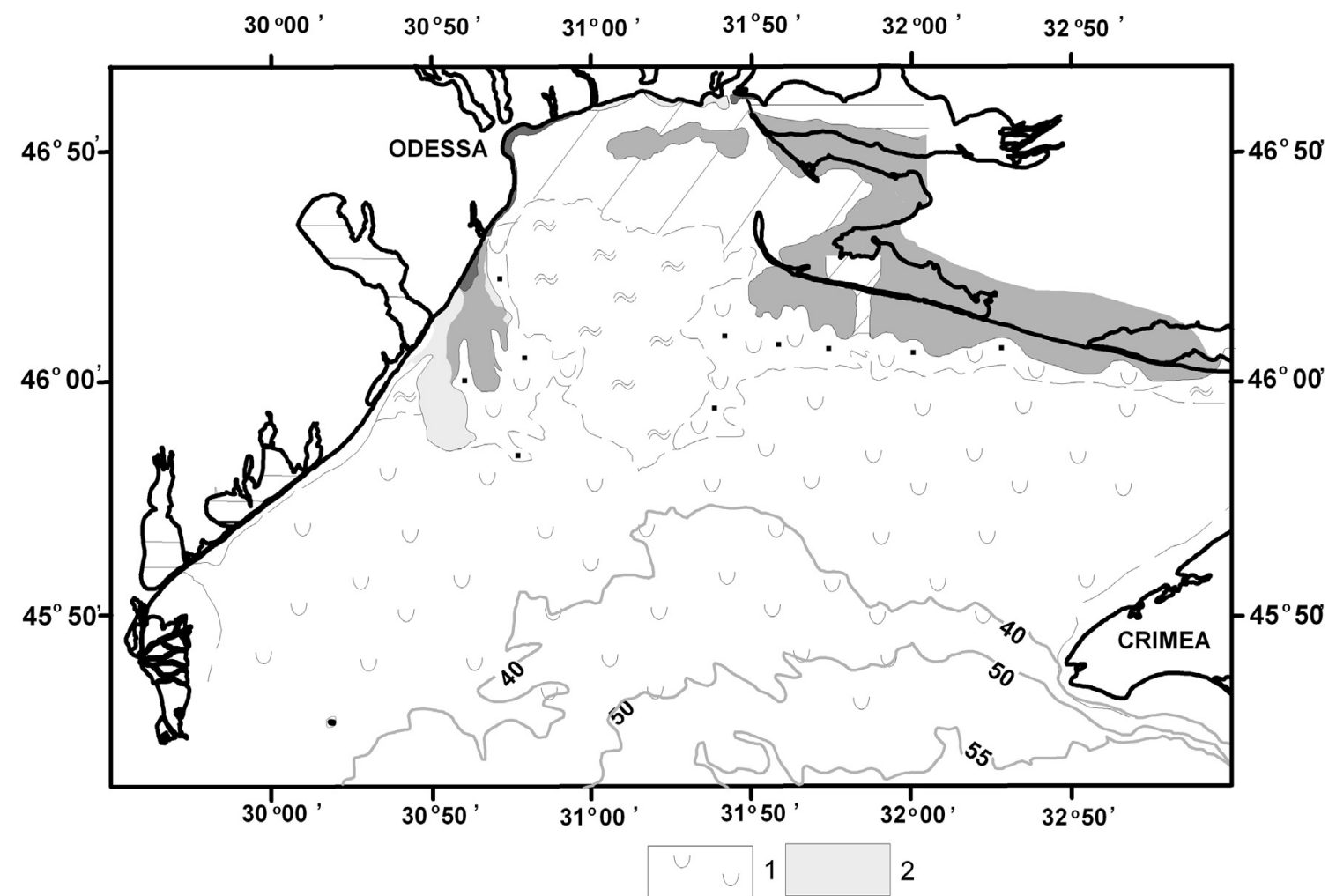

Fig. 10. Map of the Kalamitian facies. See Fig. 2 and Fig. 5 for captions. marine facies: 1. marine shell sediments; 2 . sites of erosion (the early Holocene sediments).

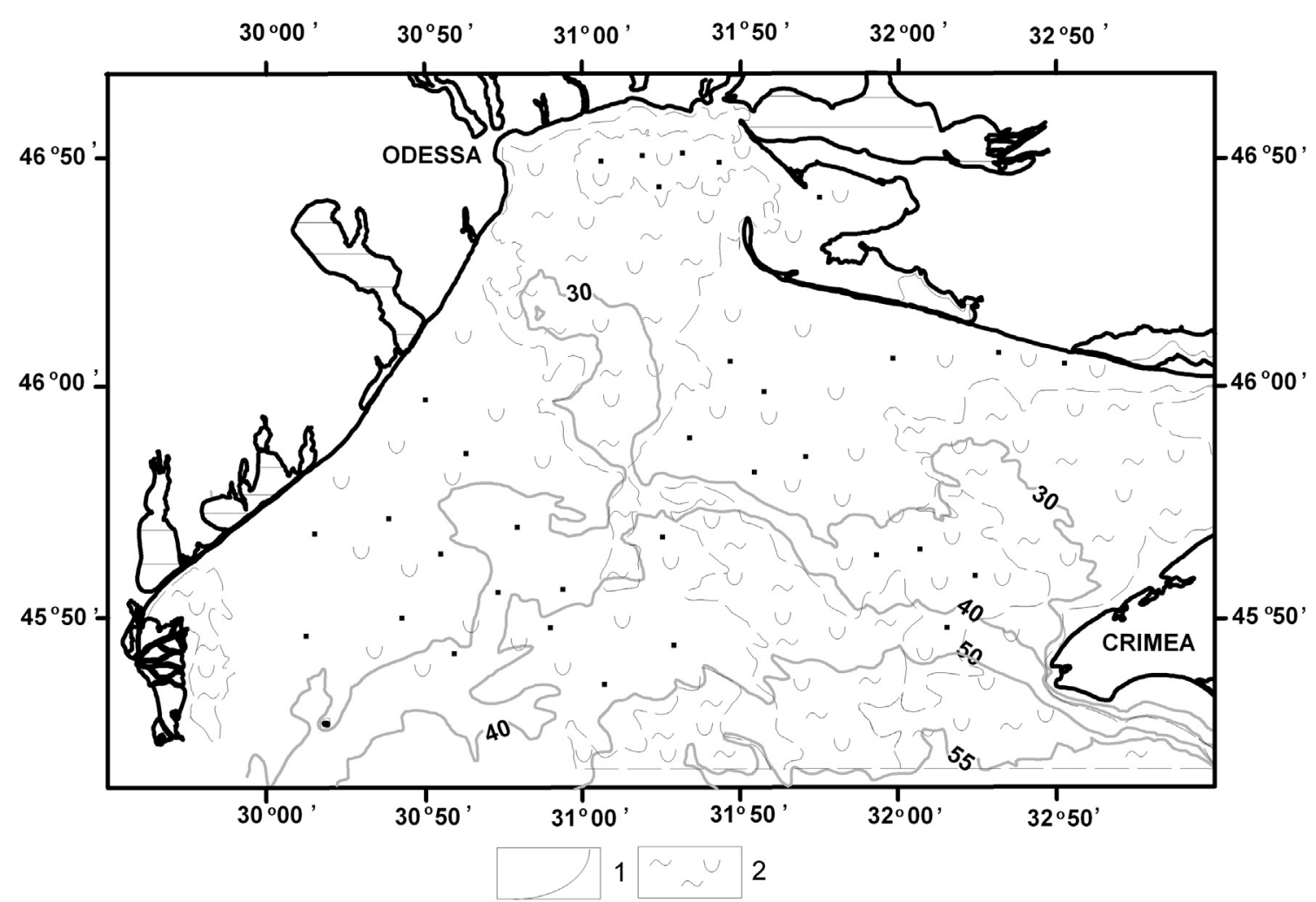

Fig. 11. Map of the recent facies. See Fig. 2 and Fig. 5 for captions. 1. present coastline; marine facies: 2 . marine silt and clayey mud with shells. 


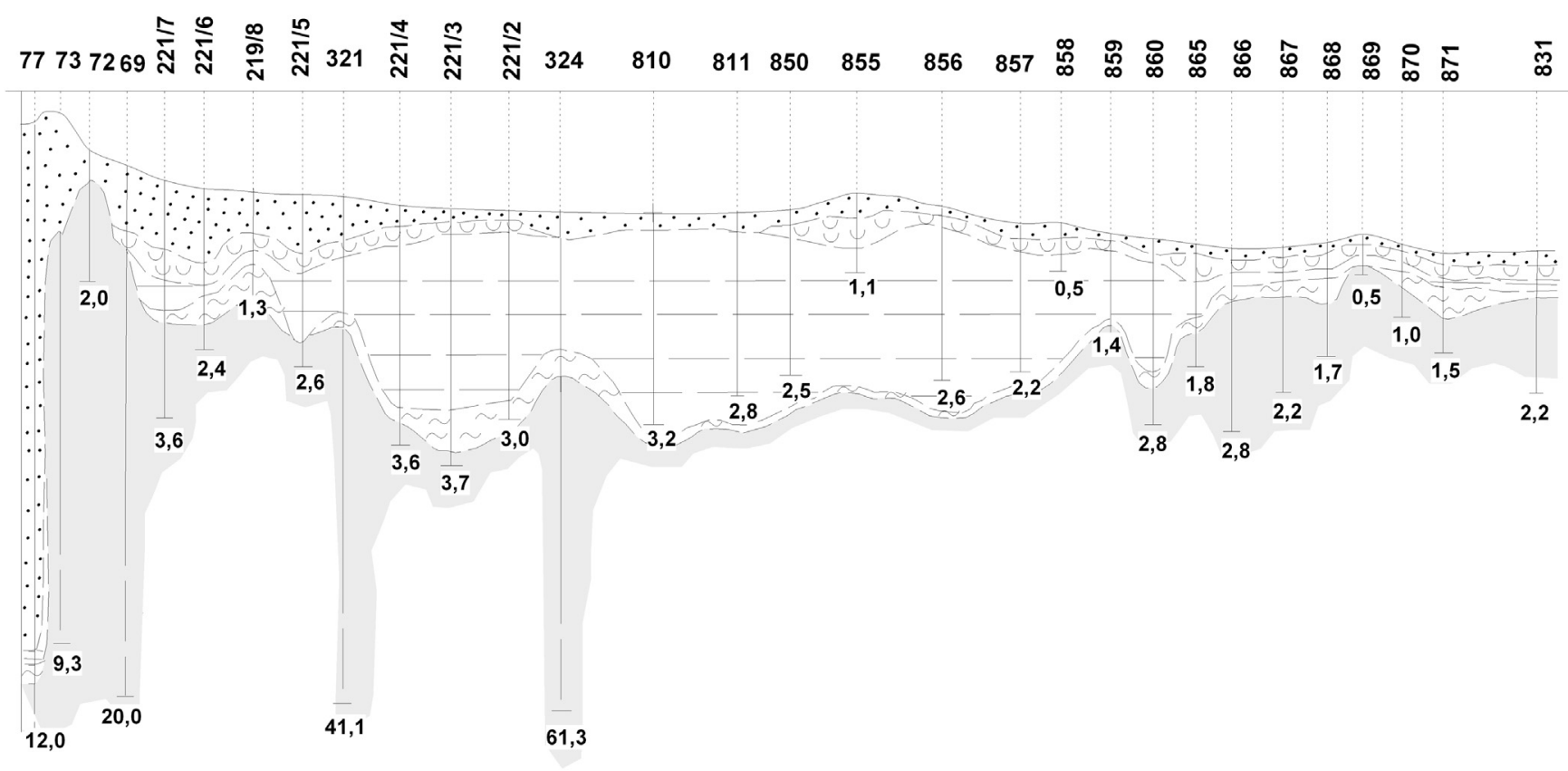

Fig. 12. Section across study area. See Fig. 3 for captions.

Mytilus sp., Cardium exiguum, Cardium edule, Spisula sp., Rissoa sp. and Chione sp. The subfacies of shell sediments and sand is distributed on higher points (Fig. 6) and consists of coarse-grained sediments, shells with sand, medium fine grained quartz sands with silt, and detritus. Mollusc assemblages contain stenohaline species such as Divaricella divaricata, Pitar rudis, Gafrarium minimum and Modiolus phaseolinus. The brackish facies are represented by quartz sands with shell detritus, dark gray, as well as by silt and clayey mud, dark gray with greenish hue. The sequence and distribution of the discrete Holocene beds is represented in Fig. 12.

Analysis of the vast data base enabled the reconstruction of the history of geological development in the northwestern Black Sea shelf during the Holocene. The early Holocene coastline was formed in the course of the ingressive pattern of the transgression, supported by the paleofacies reconstruction. Bugazian beds fill paleoriver valleys (Fig. 2). In the section across the paleo-Dnieper valley (Fig. 3), the Holocene sediment thickness is increased.

Sea level oscillation is reflected in changes in the mollusc assemblages and the bottom sediment composition. Sorokin and Kuprin (2007) described a transitional layer in the sequence of the Holocene bottom sediments. The layer contains mixed Caspian and Mediterranean mollusc fauna assemblages in the northwestern Black Sea and in the Bulgarian, Crimean and Kerch shelf areas. The deposition of this layer lasted 1.6-1.7 ky. The long period of time which was necessary to form such transitional sediments precludes a catastrophic character of the Holocene transgression in the Black Sea. Within the study area, the strong influence of the largest rivers systems such as the Danube, Dniester, Dnieper, and Southern Bug caused a strong refreshing effect which could cause a gradual and slow transition of the composition of mollusc fauna from brackish water species to marine.

Study of distribution and lithology of the Holocene bottom sediments types reveals several regressive phases between transgressions. According to the lithological changes in the cores recovered in the vicinity of the ancient coastline, changes of sedimentation environments are visible in the Bugazian beds. Marks of erosion can be encountered also in sediments which were formed from ca. 8.9-8.5 to 7.1-6.2 ka BP. In the area of Dniester liman and
Tendra spit, erosion is evident where the Drevnechernomorian sediments are exposed. After the Kalamitian (dated from ca. 7.1-6.2 to 4.1-4 ka BP) stage of the transgression, a slight drop of sea level (regression phase) occurred. The Bugazian (from ca. 10.5-10 to 8.9-8.5 ka BP) and Vityazevian (from 8.9 to 8.5 to $7.1-6.2 \mathrm{ka} \mathrm{BP}$ ) beds underlie the Dzhemetinian (4.1-4 ka BP - present) sediments in these areas.

Each stage of the Black Sea transgression is characterized by gradual change of the bottom facies, although the whole sequences of facies were not preserved not everywhere in the shelf. Granulometric characteristics of bottom sediments denote the course of the transgression with the marks of short regressions and stops in the course of sea level rise. From the analogy of the modern sedimentation environments, the following patterns can be recognized: high hydrodynamic activity in the vicinity of the coastal zone resulted in shell detritus and well-sorted sands. In contrast, shell sediments without marks of erosion, silt and mud can be encountered far from the shoreline.

\section{Conclusions}

This study carried on the Holocene sediments on the Northwestern Black Sea shelf suggests that the Black Sea reconnection with the Mediterranean Sea happened ca. 10.5-10 ka BP. From this time, the first euryhaline mollusc species in the bottom sediments can be encountered. Lacustrine conditions existed over the larger part of study area in the beginning of the Holocene. Brackish water mollusc assemblages typical for Neoeuxinian beds such as Dreissena sp. and Monodacna sp., and numerous limnetic species such as Lithoglyphus sp. and Viviparu sp. occur in the area from the recent coastline to water depths $25-35 \mathrm{~m}$. Early Holocene beds are characterized by a wide distribution of continental facies (e.g. lacustrine-marshy and alluvial). The lacustrine phase was followed by a marine phase and the transition occurred around $c a .8 .9-8.5$ ka BP. After this time, more recent Vityazevian beds are characterized by the dominance of marine facies and mollusc species including Cardium edule, Corbula mediterranea and Abra ovata. Kalamitian beds are characterized by abundance of such marine 
species as M. galloprovincialis, Cardium exiguum, Cardium edule, Rissoa parva, Rissoa membranacea, Bittium reticulatum, and M. lineatus. Recent beds (ca. 4.1-4 ka BP to present) contain stenohaline species such as M. phaseolinus, Divaricella divaricata, Pitar rudis, and Gafrarium minimum. Closer to the shoreline, molluscs such as Mytilus sp., Cardium exiguum, Cardium edule, Spisula sp., Rissoa sp. and Chione sp. are abundant. The coastline changed its shape from indented at the beginning of the Holocene, to straighter in recent times.

\section{Acknowledgements}

We are thankful to Prichernomorskoe State Regional Geological Enterprise "Prichernomor GRGP" staff for their support. Paleontological determinations were made by Gozhik, Chaus (Institution of Geological Sciences, National Academy of Sciences of Ukraine) and by Berdnikova, V (Odessa I.I.Mechnikov National University). We are very grateful to anonymous reviewers whose scrupulous editorial work and comments were helpful in improving the manuscript.

\section{References}

Aksu, A.E., Hiscott, R.N., Kaminski, M.A., Mudie, P.J., Gillespie, H., Abrajano, T., Yasar, D., 2002. Last glacial-Holocene paleoceanography of the Black Sea and Marmara Sea: stable isotopic, foraminiferal and coccolith evidence. Marine Geology 190, 119-149.

Andrusov, N.I., 1926. Paleogeographic maps of the Black Sea area during the Upper Miocene, Pliocene and after Tertiary epochs (Paleogeograficheskie karty chernomorskoi oblasti $\mathrm{v}$ verkhnemiocenovuyu, pliocenovuyu i posletretichnuyu epokhi). The Bulletin of the Moscow Society of Naturalists (Byulleten Moskovskogo obshestva ispytatelei prirody) (Geological Section) 4 (34), 185-189 (in Russian).

Arkhangelsky, A.D., Strakhov, N.M., 1938. The Black Sea Geological Structure and History of Development (Geologicheskoe stroenie i istoriya razvitiya Chernogo morya). Academy of Sciences of USSR, Leningrad (in Russian).

Balabanov, I.P., Izmailov, Ya.A., 1988. Sea-level and hydrochemical changes of the Black Sea and Azov Sea during the last 20000 years (Izmenenie urovennogo i gidrokhimicheskogo rezhimov Chernogo i Azovskogo morei za poslednie 20000 let). Vodni resursi 6, 54-62 (in Russian).

Barkovskaya, M.G., 1982. Terrigenous-mineralogical provinces of the shore line area and the Black Sea shelf (Terrigenno-mineralogicheskie provincii priurezovoi polosy i shelfa Chernogo morya). In: Problems of Shelf Geomorphology, Lithology and Lithodynamics (Problemy geomorfologii, litologii i litodinamiki shelfa), pp. 183-213 (in Russian).

Chapovsky, E.G., 1975. Laboratory Work Aimed to Study Soils and Soils Mechanics (Laboratornye raboty po gruntovedeniyu I mekhanike gruntov). Nedra, Moscow (in Russian).

Chepalyga, A.L., 2002. Black sea (Chernoe more). In: Velichko, A.A. (Ed.), Dynamics of Terrestrial Landscape Components and Inner Marine Basins of Northern Eurasia during the Last 130,000 Years (Dinamika landshaftnykh komponentov i vnutrennikh morskikh basseinov Severnoi Evrazii za poslednie 130000 let. GEOS, Moscow, pp. 170-182 (in Russian).

Chepalyga, A.L., 2006. Late Glacial Great Flood in the Ponto-caspian Basin. In: The Black Sea Flood Question: Changes in Coastline, Climate and Human Settlement, pp. 119-148.

Emelianov, V.A., Mitropolskiy, A.Y., Nasedkin, E.I., Pasynkov, A.A., Stepanyak, Yu. D. Shnyukova, E.E., 2004. Geoecology of the Black Sea Shelf of Ukraine (Geoekologiya shelfa Chernogo morya). Academperiodika, Kiev (in Russian, with English Abstract).

Fedorov, P.V., 1978. The Pleistocene of the Ponto-caspian (Pleistotsen Ponto-Kaspiia). Nauka, Moscow (in Russian).

Fesyunov, O.E., 2000. Geoecology of the Northwestern Black Sea Shelf (Geoekologiya severo-zapadnogo shelfa Chernogo morya). Astroprint, Odessa (in Russian).

Giosan, L., Filip, F., Constatinescu, S., 2009. Was the Black Sea catastrophically flooded in the early Holocene? Quaternary Science Reviews 28 (1-2), 1-6.

Gozhik, P.F., Maslun, N.V., Plotnikova, L.F., Ivanik, M.M., Yakushin, L.M., Ishenko, I.I., 2006. Stratigraphy of Mesozoic and Cenozoic Deposits of the Black Sea Northwestern Shelf (Stratygrafiya mezokainozoiskikh vidkladiv pivnichnozakhidnogo shelfu Chornogo morya). Logos, Kiev (in Ukrainian, with English Abstract).

Ishenko, L.V., 1971. Sediments 'dynamics of shelf upper area in the Dniester liman seashore (Dinamika nanosov verkhnei chasti shelfa na vzmorie Dnestrovskogo limana). In: Nevessky, E.N., Leontiev, O.K. (Eds.), Geomorphology and Lithology of Shore Area of Seas and Other Large Basins (Geomorfologiya i litologiya beregovoi zony morei i drugikh krupnykh vodoemov). Nauka/USSR, Moscow, pp. 148-154 (in Russian).
Ivanova, E.V., Murdmaa, I.O., Chepalyg, A.L., Cronin, T.M., Pasechnik, I.V., Levchenko, O.V., Howe, S.S., Manushkina, A.V., Platonova, E.A., 2007. Holocene sea-level oscillations and environmental changes on the Eastern Black Sea shelf. Palaeogeography, Palaeoclimatology, Palaeoecology 246, 228-259.

Konikov, E.G., 2007. Modeling of sedimentation processes within the northwestern Black Sea shelf during the Late Neoeuxinian and Holocene (Mode processa osadkonakopleniya na severo-zapadnom shelfe Chernogo moray v pozdem novoevksine i golocene). Geology and Mineral Resources of Word Ocean (Geologiya i poleznie iskopaemye Mirovogo okeana) 2, 34-47 (in Russian).

Lericolais, G., Popescu, I., Guichard, F., Popescu, S.M., 2007. A Black Sea Lowstand at 8500 Yr B.P. Indicated by a Relict Coastal Dune System at a Depth of $90 \mathrm{M}$ below Sea Level. Coastline Changes: Interrelation of Climate and Geological Processes, vol. 426. The Geological Society of America, pp. 171-188. Special Paper.

Major, C.O., Goldstein, S.L., Ryan, W.B.F., Lericolais, G., Piotrowski, A.M., Hajdas, I., 2006. The co-evolution of Black Sea level and composition through the last deglaciation and its paleoclimatic significance. Quaternary Science Reviews 25 (17-18), 2031-2047.

Mitropolskiy, O.Yu., Nasedkin, E.I., Osokina, N.P., 2006. Ecological Geochemistry of the Black Sea. Kiev (Geoekokhimiya Chornogo morya). (in Ukrainian).

Molodikh, I.I., Usenko, V.P., Palatnaya, N.N., Kochubey, N.I., Polozhevetc, M.F. Gozhik, P.F., Garkusha, N.A., Ponomarenko, V.D., Martynov, V.S., Boltivetc, V.A., Novoselskiy, F.A., Slipchenko, P.S., Rotar, M.F., Voskoboynikov, V.M., Konikov, E.G., Naumenko, P.N., Palienko, E.T., Stetcyuk, V.V., 1984. In: Shnyukov, E.F. (Ed.), Geology of the USSR's Shelf. Limans (Geologiya shelfa USSR. Limany). Naukova dumka, Kiev (in Russian).

Nevesskaya, L.A., Nevesskiy, E.N., 1961. About fauna composition and the Azov-Black Sea basin development features in the Late-Quaternary period ( $O$ sostave fauny I osobennostyakh razvitiya Azovo-Chernomorskogo basseina v poznechetvertichnoe vremya). Preceedings of Academy of Sciences of USSR 136 (5), 215-218 (in Russian).

Nevesskaya, L.A., 1965. Late Quaternary Bivalve Molluscs of the Black Sea, Their Systematics and Ecology (Pozdnechetvertichnye dvustvorchatye molliuski Chernogo Moria, ikh sistematika i ekologiia). Trudy Paleontologicheskogo Instituta Akademii Nauk SSSR 105. Nauka, Moscow. (in Russian).

Nevesskiy, E.N., 1967. Sediment Forming Processes in the Sea Shore Zone (Processy osadkoobrazovaniya $\mathrm{v}$ pribrezhnoi zone morya) (in Russian). Nauka, Moscow.

Pazyuk, L.I., Ishenko, L.V., Rychkovskaya, N.I., 1977. Heavy minerals distribution regularity of terrigenous sediments along the Northwestern Black Sea seashore zone (Zakonomernosti raspredeleniya tyazhelykh mineralov terrigennykh otlozheniy po prostiraniyu pribrezhnoi zony severo-zapadnogo shelfa Chernogo morya). Mineralogy of Sedimentalogical Units (Mineralogiya osadochnikh obrazovaniy) 4, 58-74 (in Russian).

Petelin, V.P., 1967. Granulomery Analysis of Marine Bottom Sediments (Granulometricheskiy analiz morskikh donnykh osadkov). Nauka, Moscow (in Russian).

Ryan, W.B.F., Vachtman, D., McHugh, C., Cagatay, M.N., Mart, Y., 2013. A channeled shelf fan initiated by flooding of the Black Sea. In: Goffredo, S., Dubinsky, Z. (Eds.), The Mediterranean Sea: its History and Challenges. Springer-Verlag, Berlin (in press).

Ryan, W.B.F., Pitman III, W.C., Major, C.O., Shimkus, K., Moskalenko, V., Jones, G.A. Dimitrov, P., Gorur, N., Yuce, H., 1997. Abrupt drowning of the Black Sea shelf. Marine Geology 190, 119-126.

Ryan, W., Major, C., Lericolais, G., Goldstein, S.L., 2003. Catastrophic flooding of the Black Sea. Annual Review Earth and Planetary Scences 31, 525-554.

Sibirchenko, M.G., Karpov, V.A., Ivanov, V.G., 1983. Technical Report About Bottom Sediments Lithological Composition in the Black Sea for the Purposes of Geological-lithological Map Compilation. Marine Geological Survey Detachment SRGE "Prichernomorgeologiya”, Odessa, Ukraine (in Russian).

Sherbakov, F.A., Morgunov, Yu.G., 1975. Newest Tectonic of the Black Sea Shelf's Northwestern Part (Noveishaya tektonika severo-zapadnoy chasti Chernogo morya). In: Problems of Shelf s Geology (Problemy geologii shelfa), pp. 159-165 (in Russian).

Shnyukov, E.F., Melnik, V.I., Inozemcev, Yu.I., Kholosheva, D.P., Tcykhotskaya, N.N., Lutcyv, Ya.K., Ogorodnikov, V.I., Grigoriev, A.V., Bondarenko, V.G., Frolova, L.M. Lebedev, Yu.S., Kirichenko, O.N., Ivanov, Yu.K., Alenkin, V.M., Morgunov, Yu.G., Limonov, A.F., Kuprin, P.N., Fedorov, P.V., Sherbakov, F.A., Balandin, Yu.G. Naumenko, P.I., Voskoboynikov, V.M., Krakovskiy, B.I., Konikov, E.G., Yanko, V.V., Kotlov, V.F., Shekhotkin, V.V., 1985. In: Shnyukov, E.F. (Ed.), Geology of the USSR's Shelf. Lithology (Geologiya Shelfa USSR. Litologiya). Naukova dumka, Kiev (in Russian).

Shnyukov, E.F., Ivannikov, A.V., Kobolev, V.P., Stazhilov, A.G., Kleshenko, S.A. Blokhina, T.S., Kutas, R.I., Korchagin, I.N., Ziborov, A.P., Inozemtcev, Yu.I., 1998. Geology, Geophysics and Hydrography of the Northwestern Part of the Black Sea (Geologiya, geofizika i gidrografiya severo-zapadnoi chasti Chernogo morya). Kiev. (in Russian).

Sorokin, V.M., Kuprin, P.N., 2007. About the Character of the Black Sea Level Upraise during the Holocene ( $\mathrm{O}$ kharaktere podioma urovnya Chernogo morya v golocene), vol. 5. Bulletin of Moscow University (Vestnik moskovskogo universiteta). Series 4, pp. 40-46. (in Russian, with English Abstract).

Tsereteli, D.V., 1975. About synchronicity of the Late Glacial and Post Glacial evolution of the Black and Baltic Seas (O sinchronnosti pozdne- i poslelednikovoi istorii razvitia Chernogo i Baltiiskogo basseinov) Coordination Centre for the Member Countries of the Council for Mutual Economic 
Assistance, Comecon, on World Ocean Problems (Kordinatsionnyi tsent stran-chlenov SEV po problemam mirovogo okeana) Economic Assistance, Comecon, on World Ocean Problems. Informatsionnii biulleten 3, 72-83 (in Russian).

Tyuleneva, N.V., 2010. Sediment forming conditions within the north-west Black sea shelf during Bugazian time (Early Holocene) (Usloviya osadkonakopleniya na severo-zapadnom shelfe Chernogo moray v Bugazskoe vremya (Ranniy golocen)). Geology and Mineral Resources of Word Ocean (Geologiya i poleznye iskopaemye Mirovogo okeana) 4, 65-74 (in Russian, with English Abstract)

Tyuleneva, N.V., Suchkov, I.A., 2011. Holocene coastlines position reconstruction within the northwestern Black Sea Shelf. In: Proceedings, International Conference on Caspian-black Sea Mediterranean Corridor during Last $30 \mathrm{ka}$ : Sea Level Change and Human Adaptive Strategies. INQUA 501. Astroprint, Odessa, Ukraine, pp. 171-173.

Yanko, V.V., 1989. Quaternary Foraminifera of the Pontic-caspian Region (The Black Sea, Sea of Azov, Caspian Sea, and Aral Sea): Taxonomy, Biostratigraphy, History, Ecology (Chetvertichnie foraminiferi Ponto-Kaspiia (Chernoe Azovskoe, Kaspiiskoe i Aral'skoe moria): taxonomiia, biostratigrafiia, istoriia razvitia, ecologiia) (PhD thesis). Moscow State University, Russia (in Russian).

Yanko, V.V., 1990. Stratigraphy and paleogeography of marine Pleistocene and Holocene deposits of the southern seas of the USSR. Memorie della Società Geologica Italiana 44, 167-187.

Yanko-Hombach, V.V., 2007. Controversy over Noah's Flood in the Black Sea: geological and foraminiferal evidence from the shelf. In: Yanko-Hombach, V., Gilbert, A.S., Panin, N., Dolukhanov, P.M. (Eds.), The Black Sea Flood Question: Changes in Coastline, Climate, and Human Settlement. Springer, Dordrecht, pp. 149-204.

Yanko-Hombach, V.V., Smyntyna, E.V., Kadurin, S.V., Larchenkov, E.P., Motnenko, I.V., Kakaranza, S.D., Kiosak, D.V., 2011. Oscillations of the Black Sea level and ancient human adaptive strategy during the last $30 \mathrm{ka}$ (Kolebaniya urovnya Chernogo moray i adaptacionnaya strategiya drevnego cheloveka za poslednie 30 tysyach let). Geology and Mineral Resources of Word Ocean (Geologiya i poleznye iskopaemye Mirovogo okeana) 2, 61-94 (in Russian, with English Abstract).

Zenkovich, V.P., 1962. Study About Marine Shores Development (Osnovy ucheniya o razvitii morskikh beregov). Nauka, Moscow (in Russian). 